\title{
A Comparative Review of Canadian Health Professional Education Accreditation Systems
}

\author{
Vernon R. Curran, $\mathrm{PhD}$ \\ Memorial University of Newfoundland \\ Lisa Fleet, MA \\ Memorial University of Newfoundland \\ Diana Deacon, MEd \\ Memorial University of Newfoundland
}

\begin{abstract}
Canadian governments and various stakeholder groups are advocating greater interprofessional collaboration amongst health care providers as a fundamental strategy for enhancing coordination and quality of care in the health care system. Interprofessional education for collaborative patient-centred practice (IECPCP) is an educational process by which students/learners (or workers) from different health professions learn together to improve collaboration. The educational system is believed to be a main determinant of interprofessional collaborative practice, yet academic institutions are largely influenced by accreditation, certification and licensure bodies. Accreditation processes have been linked to the continuous improvement of curricula in the health professions, and have also been identified as potential avenues for encouraging educational change and innovation. The purpose of this paper is to summarize the characteristics of the national accreditation systems of select Canadian health professional education programs at both the pre- and post-licensure educational levels and to show how these systems support and/or foster IECPCP. A
\end{abstract}


review of the educational accreditation systems of medicine, nursing, pharmacy, social work, occupational therapy and physiotherapy was undertaken through key informant interviews and an analysis of accreditation process documentation. The results of this comparative review suggest that accreditation systems are more prevalent across the health professions at a pre-licensure level. Accreditation at the postlicensure level, particularly at the continuing professional education level, appears to be less well established across the majority of health professions. Overall, the findings of the review also suggest that current accreditation systems do not appear to promote nor foster interprofessional education for collaborative patient-centred practice in a systematic manner through either accreditation processes or standards. Through a critical adult learning perspective we argue that in order for traditional uni-professional structures within the health professional education system to be challenged, the accreditation system needs to place greater value on interprofessional education for collaborative patient-centred practice.

\section{RÉSUMÉ}

Les gouvernements du Canada ainsi que divers groupes d'intervenants appellent à une plus grande collaboration interprofessionnelle entre les fournisseurs de services de santé comme stratégie fondamentale pour rehausser la coordination et la qualité des soins dans le système des soins de santé. L'éducation interprofessionnelle pour la pratique collaborative centrée sur le patient (IECPCP) constitue un processus éducatif qui permet aux étudiants/apprenants (ou travailleurs) de diverses professions de la santé d'apprendre ensemble à mieux collaborer. Le système éducatif est perçu comme le principal déterminant de la pratique collaborative interprofessionnelle; cependant, les institutions éducatives sont fortement influencées par les organismes qui octroient les accréditations, certifications et autorisations d'exercer. Les processus d'accréditation ont été reliés à l'amélioration continue des programmes d'études dans les professions de santé et ils ont été également identifiés comme avenues potentielles pour encourager le changement et l'innovation en milieu éducatif. L'objectif de cet article est de résumer les caractéristiques des systèmes nationaux d'accréditation de certains programmes de formation des professionnels de la santé au Canada à tous les niveaux (pré- et post-autorisation d'exercer) et de montrer comment ces systèmes soutiennent ou encouragent l'IECPCP. Nous avons passé en revue les systèmes d'accréditation en médecine, soins infirmiers, pharmacie, travail social, ergothérapie et physiothérapie par le biais d'entrevues avec des personnes-clés et par l'analyse de la documentation sur les processus d'accréditation. Les résultats de cette étude comparative suggèrent que les systèmes d'accréditation dans les 
services de santé sont plus courants avant l'octroi de l'autorisation d'exercer. L'accréditation post-autorisation d'exercer, en particulier dans le domaine de la formation professionnelle continue, semble être moins bien établie dans la majorité des professions de la santé. Globalement, les résultats de l'étude suggèrent aussi que les systèmes actuels d'accréditation ne semblent pas promouvoir ou encourager la formation interprofessionnelle pour la pratique collaborative centrée sur le patient de façon systématique par les processus ou normes d'accréditation. Dans la perspective critique de l'apprentissage des adultes, nous avançons que, pour remettre en question les structures uniprofessionnelles traditionnelles du système éducatif des professions de la santé, le système d'accréditation doit accorder une plus grande

place à l'éducation interprofessionnelle sur la pratique collaborative centrée sur le patient.

\section{INTRODUCTION}

It has been suggested that a collaborative practice approach, involving interprofessional teams of health care providers offering comprehensive and coordinated health care services, is one fundamental way to enhance the Canadian health care system (Health Council of Canada, 2005; Kirby, 2002; Romanow, 2002). Drinka (1996) defines an interprofessional health care team as a group of health professionals from different professions who engage in planned, interdependent collaboration. Interprofessional approaches to patient care are believed to have the potential to improve professional relationships, increase efficiency and coordination, and ultimately enhance patient and health outcomes (Reeves \& Freeth, 2002).

In Canada, interprofessional education for collaborative patient-centred practice (IECPCP) is being advocated as a key strategy for ensuring that health care practitioners have the knowledge, skills, and attitudes to practice together in an effective collaborative manner (Oandasan \& Reeves, 2005a). Interprofessional education has been defined as a process by which a group of students/learners (or workers) from health-related occupations with different educational backgrounds learn together during certain periods of their education to improve collaboration and the quality of care (Areskog, 1988; CAIPE, 1997). Interprofessional education may be introduced at either a prelicensure or post-licensure level. Pre-licensure education occurs while students/ learners are in their formal years of learning, before receiving a license to practice independently. Post-licensure education signifies education that occurs once a health professional is practicing independently and can take the form of continuing professional development as well as graduate education (Oandasan \& Reeves, 2005a).

Research has found that interprofessional education helps learners better understand the roles, responsibilities, strengths and limitations of other professions (Clark, 1991; Parsell, Spalding \& Bligh, 1998; Parsell \& Bligh, 
1999). The World Health Organization (1988) reports that interprofessional education helps members of the health care team to develop mutual respect and understanding for one another. Other advantages identified by Parsell et al. (1998) and Parsell and Bligh (1999) include improved relationships with other disciplines, increased trust, dispelling of stereotypes, and significantly improved attitudes towards other professional groups.

D'Amour and Oandasan (2005) suggest that the educational system is a main determinant of interprofessional collaborative practice as it promotes the fostering of collaborative values among future health care professionals. Oandasan and Reeves (2005b) note that academic institutions are influenced by accreditation, certification, and licensure bodies. Accreditation at institutions where health professionals work or are trained can act as powerful forces for change (D'Amour \& Oandasan, 2005). In the United States, the Institute of Medicine has used this influence to encourage health professional programs to introduce changes in the ways that health professional students are educated. The inclusion of interprofessional education in accreditation standards may therefore be one means for promoting and fostering its integration within health professional education programs.

Accreditation typically involves evaluating a program's compliance with a minimum set of acceptable standards based on professional and educational criteria (Leist, Gilman, Cullen, \& Sklar, 2004). At its core, accreditation is an evaluative process. It also provides a strong incentive for quality improvement. Encouraging a culture of quality can enable program and curriculum improvement. Accreditation processes and agencies have also been identified as potential avenues and agents for leading and encouraging educational change (Gelman, 1997; Hamilton, 1995; Kassebaum, Cutler, \& Eaglen, 1997).

The first efforts towards accrediting health professional education programs occurred in the early twentieth century when an accreditation system for medical schools was estasblished through the American Medical Association (AMA) (Sullivan, 1994). According to the Association of Accrediting Agencies of Canada (AAAC) the accreditation process serves to determine and certify the achievement and maintenance of reasonable and appropriate national standards of education for professionals (Association of Accrediting Agencies of Canada, 2005a, 2005b, 2005c). The Council for Higher Education Accreditation has identified a key role for accreditation to include serving public interest and need (Eaton, 2003). Accreditation is particularly important for health professional education in a climate of system change and social accountability (Sullivan, 1994; Thomas, Arsenault, Bouchard, Coté, \& Stanton, 1992).

The accreditation process has been intricately linked to the continuous improvement and enhancement of curricula and programs in the health professions. A number of reviews of the Liaison Committee for Medical Education (LCME) accreditation process have demonstrated a connection to improved quality of curricula in medical programs and to the overall quality of physician training (Kassebaum, 1992; Kassebaum \& Cohen, 2000; Schwarz, 1992). An 
evaluation of accreditation of nursing programs by the Canadian Association of University Schools of Nursing (CAUSN) indicated that, "the process fosters growth, promotion and self-development” (Thomas \& Arsenault, 1993, p.84).

Promotion and fostering of collaborative practice within the Canadian health system is believed to be intricately linked and interrelated to the extent to which interprofessional education at both pre and post-licensure levels of health professional education enhances health professionals' competencies for interprofessional teamwork. The Canadian health professional education system has not traditionally established or introduced interprofessional education as a significant aspect in the pre or post-licensure education of health professionals. Rather, health professionals have continued to be educated and trained in isolation from one another. As a result, this approach has perpetuated uniprofessional modes of practice, as well as inaccurate misconceptions and stereotypes. Accreditation systems of health professional education are considered important in influencing change and the adoption of new innovations in health professional education curricula. To date, the extent to which the current systems of health professional accreditation in Canada supports interprofessional education in formal and explict manners has not been fully explored in a systematic manner.

The purpose of this paper is twofold: first, to summarize the characteristics of national accreditation systems of select Canadian health professional education programs at both pre- and post-licensure educational levels, and second, to examine how these systems currently support or foster IECPCP. The professional education programs included in this review are medicine, nursing, pharmacy, social work, physiotherapy, and occupational therapy.

\section{RESEARCH DESIGN}

An examination of national accreditation systems for select Canadian health professional education programs was undertaken using key informant interviews and a review of accreditation documentation gathered from organizational web sites and accreditation bodies. Semi-structured interviews were conducted with 13 senior administrators or directors of organizations or bodies responsible for accrediting or administering accreditation programs at the pre-licensure and postlicensure education levels. These respondents were asked to describe the general nature of the academic accreditation system and specific characteristics of the accreditation process for their respective professions. Interviews were conducted by telephone and tape recorded. The purpose of the web site reviews were to identify and compile accreditation-related documentation and to supplement and verify the information that had been collected via the key informant interviews. Web sites were searched for documents and information related to "accreditation," "education," "credentialing," "standards," "certification," and "professional development." Accreditation standards and documents were downloaded, compiled, and reviewed. 


\section{RESULTS}

Appendix A identifies the accrediting bodies for each of the health professional education programs reviewed in this paper, as well as the key standards or categories of standards that encompassed the accreditation process for each program area. A national academic accreditation system exists at a pre-licensure level for each of the undergraduate health professional education programs reviewed. The cycle of accreditation at the undergraduate level was similar across accrediting bodies with the maximum length for full accreditation status in most instances ranging between five to eight years. The systems of accreditation also included similar processes, including some form of institutional self-study, completion and submission of a self-study report, site visits by accreditation teams, and preparation and submission of a final report to an accreditation committee or council for review and final decision making. The results presented here represent the state of these accreditation systems as of November 2004.

Health professional education programs at a graduate, post-licensure level in Canada generally followed the same accreditation model as undergraduate level programs. In many of the professions, graduate programs at the time of the study were included as part of the same accreditation process for prelicensure programs with variations, in some instances, in the standards which are applied. The accreditation process was voluntary at the graduate level for a number of the professions and the majority utilized some combination of an institutional self-study and site visit by teams of peer surveyors.

Graduate nursing programs in Canada were not accredited by a national body at the time of the study. University-level programs (i.e., masters, doctoral) were normally reviewed in accordance with the regulations or academic guidelines of the host institution. The physiotherapy profession was moving towards a standard of graduate-level education for entry into the profession. No accreditation system for graduate level programs was in place in Canada at the time the review was conducted. The Canadian Association of Occupational Therapy (CAOT) accredited occupational therapy university programs at the masters level. Similarly, the educational programs for the occupational therapy profession in Canada were also in transition towards masters level training as the standard for entry into this profession.

Continuing professional education (CPE) comprises all those formal, informal and nonformal learning activities which are intended to enhance and maintain the competencies of professionals. CPE takes place once a professional has completed pre-licensure education and has entered practice. It may include mandated participation in learning activities required to maintain licensure or registration (e.g., mandatory continuing education (MCE)) or learning which is self-directed.

Family physicians and specialists in Canada are required to participate in continuing medical education (CME) if they are certified members of their respective colleges - the College of Family Physicians of Canada (CFPC) or the 
Royal College of Physicians and Surgeons of Canada (RCPSC). Accreditation at the CME level may be characterized by two distinct levels: program accreditation and provider accreditation. Program accreditation is overseen by either the CFPC or the RCPSC. CME programs for family physicians are accredited by the CFPC and this system is known as Mainpro (Maintenance of Proficiency/ Maintien de la compétence professionnelle). All Mainpro-M1 or C activities ${ }^{1}$ offered by an accredited provider must be planned and organized according to certain standards in order to be offered as accredited activities. CME programs in Québec for family physicians can also be accredited by the Fédération des médecins omnipracticiens du Québec (FMOQ) and the Association des médecins de langue francaise du Canada (AMLFC). Specialists who are Fellows (i.e., members) of the RCPSC are required to participate in CME for re-certification over a five-year cycle. The CME system of the RCPSC is known as Maincert (Maintenance of Certification). All activities of an accredited provider are automatically approved by the RCPSC for Maincert accreditation.

CME for physicians may be provided by either the CFPC or RCPSC or provincial affiliates, universities, national or provincial professional associations, private industry (i.e., pharmaceutical or communications companies), and health care institutions. There is a formal system in place which accredits universities and National Specialty Societies (NSS) as providers of accredited CME. Third parties (i.e., private industry) are not accredited and as such, must be sponsored by and work in partnership with an accredited provider. Accreditation of universities as CME providers outside Québec is conducted by the Association of Faculties of Medicine of Canada (AFMC) Committee on Accreditation of Continuing Medical Education (CACME). Québec universities are accredited by both CACME and the Collège des médecins du Québec (CMQ). The RCPSC accepts CACME accreditation for universities, whereas national specialty societies have to apply to the RCPSC for accreditation.

At the time of the study, the majority of provinces and territories did not require CPE program or provider accreditation for nurses. Six provinces (British Columbia, Saskatchewan, Manitoba, Ontario, Nova Scotia, and Prince Edward Island) and two territories (Northwest Territories and Nunavut) had legislation that mandated nurses to participate in some form of CPE for re-registration (re-licensure). In the majority of these provinces and territories, this mandatory CPE system was based on "Continuing Competence" Programs. Although the Canadian Nurses Association (CNA) does not accredit continuing professional education programs or providers, it does provide some guidelines for continuing nursing education programs. The purpose of these guidelines is threefold: (1) to help in the development of programs; (2) to help nurses select appropriate programs; and (3) to serve as a standardized guide for programs, thus facilitating the portability of courses across provincial and territorial boundaries (Canadian Nurses Association, 1992).

CPE programs offered to pharmacists across more than one province or territory are accredited at the national level by the Canadian Council on 
Continuing Education in Pharmacy (CCCEP). At the time of the review, there was no formal process in place for CPE provider accreditation in pharmacy; however, a pilot project was being undertaken by the CCCEP for accrediting providers. Continuing education program accreditation for pharmacists varied at the provincial level. Seven provinces (British Columbia, Alberta, Saskatchewan, Manitoba, Québec, Nova Scotia, and Newfoundland and Labrador) required accreditation for at least some of the CPE programs in which pharmacists participated. These programs were normally accredited by the respective provincial regulatory body or association.

At the time of the study, six provinces (Alberta, Saskatchewan, Manitoba, New Brunswick, Nova Scotia, and Newfoundland and Labrador) mandated social workers to participate in some form of CPE for re-licensure. Both formal and informal methods of CPE were generally acceptable across most provinces. CPE program accreditation was required for the social work profession in Alberta and Saskatchewan, but the regulatory authority in both provinces had not established specific standards for CPE provider accreditation.

There was no formal system in place in Canada for the accreditation of CPE programs and/or providers of CPE for physiotherapists. Several provinces had initiated voluntary programs encouraging physiotherapists to prepare continuing competency portfolios that promoted their participation in a range of formal and informal CPE activities. Prince Edward Island and Ontario had legislation that mandated physiotherapists to participate in some form of CPE for re-licensure. At the time of the review, British Columbia, Alberta, Saskatchewan, and New Brunswick were developing or finalizing mandatory continuing competence programs of which some form of CPE would be a part.

There was no formal system in place in Canada for the mandatory accreditation of CPE programs and/or providers of CPE for occupational therapists. The Canadian Association of Occupational Therapists established standards for the "endorsement" of continuing professional education, but did not accredit CPE programs, institutions or providers.

Most of the accreditation systems reviewed demonstrated relatively few, if any, specific standards or criteria related to IECPCP. The relationship between IECPCP and the accreditation of CPE programs or providers in the health professions was, in most cases, underdeveloped. At a postgraduate medical education level, the development of the Canadian Medical Education Directions for Specialists 2000 Project (CanMEDS) framework and associated competency roles has been a central element for the revision and updating of standards for postgraduate medical education. In particular, the role of "collaborator" is a key competency related to interprofessional education for collaborative patient-centred practice. This role emphasizes the significance of skills in consulting effectively with other health care professionals and contributing effectively to interdisciplinary team activities. Evidence of training to develop competencies in this role must be demonstrated by residency programs as part of the accreditation process. 
Academic accreditation standards for pharmacy and social work undergraduate education programs partly addressed IECPCP. For pharmacy, this was covered under Guideline 5.2:

The University should facilitate interprofessional health science education. Professional programs in pharmacy should benefit from association with other health science programs including shared didactic and clinical experiences and the utilization of common physical and clinical facilities. (Canadian Council for the Accreditation of Pharmacy Programs, 2004)

The standards for accreditation of social work programs contained multiple references to the value and importance of collaboration with other professionals in the community. Schools are required to establish and maintain collaborative relationships with other professionals and professional organizations relevant to their programs. The curriculum must also include knowledge of other professions to facilitate collaboration and teamwork.

\section{DISCUSSION}

This comparative review of accreditation systems of Canadian health professional education suggests that accreditation systems were more prevalent at a pre-licensure level. The pervasiveness of accreditation systems at this level supported the significance of pre-licensure education as a measure of accountability, especially to society, of the competence of individuals to enter practice. Accreditation at the post-licensure level, particularly the CPE level, appeared to be less well established across the majority of health professions reviewed.

D'Amour and Oandasan (2005) suggest that the professional system strongly influences the development of collaborative practice in the health system. Traditionally, the professional system has been based on separate "silos" of professional practice which act as barriers in different ways to collaborative practice (Gilbert, 2005; Hall, 2005; Lahey \& Currie, 2005). The history of the "professions" is based on connotations of autonomy, hierarchy, and control. Lahey and Currie (2005) suggest that self-regulating professions tend to focus their professional interest in maintaining control over a plot of occupational turf rather than their obligation to serve the broader public interest. Furthermore, students are immersed in philosophies, values and basic theoretical perspectives inherent to their specific profession during the entire professional socialization phase of learning. In most health professional education programs, the value system is assumed rather than explored, and inculcated rather than examined. This approach may be an effective way to indoctrinate students, but it may also prove detrimental later in their professional lives when their values are called into question. Students quickly learn that the process of professional acculturation is important to their doing well in their studies. Teaching and 
learning experiences often reinforce the solitary nature of learning, with few courses emphasizing the importance of teamwork or working in small groups. In many ways, such practices work against notions of collaboration.

Professional associations seek autonomy and respect for their members. These aims influence whether the associations fully acknowledge the role and place of other health professions in the health care system. Professional associations, therefore, significantly influence IECPCP. The professional associations are responsible for advocating standards of practice within a profession, identifying ethical standards, and establishing practice competencies. Through provincial legislation, the professional system in Canada is also responsible for regulating and defining scope of practices (Lahey \& Currie, 2005). Current regulatory models determine the legal effect of each scope of practice on the ability of other providers to fully apply their competency to the benefit of patients and the system (Lahey \& Currie, 2005). As a result, the regulatory bodies within the professional system strongly influence the advancement of IECPCP. Lahey and Currie (2005) recommend that cultural practices at the regulatory level must be transformed in the same way that clinical practice has been transformed by the demands of interprofessional practice.

Merriam and Caffarella (1999) suggest that a critical perspective on adult learning entails questioning power relations which exist within the context where learning takes place, the larger systems in society, the culture and institutions that shape learning, and the structural and historical conditions framing and defining learning events. A critical adult learning perspective would also raise questions regarding whose interests are being served by programs being offered, who holds the power to make changes, and the intended and unintended outcomes that result from the way adult education and learning opportunities are structured. Because this stance critiques and raises questions about the assumptions we make about the world around U.S., including those underlying the practice of adult education, it has been called "critical adult education" (Merriam \& Caffarella, 1999, p.341).

Welton (1993) believes the "system," representing structures of power (institutions and organizations), as well as the means to power (such as knowledge) may be oppressive rather than emancipatory for the common good of society. Welton also suggests that to counter the hegemony of the system and redress existing imbalances and contradictions, stakeholders must engage in a rational discourse about sources of power. Therefore, by viewing the current health professional education system through a critical adult learning perspective, we can appreciate how this system has traditionally functioned to reproduce the status quo of health professional students/learners trained in isolation from one another.

Nesbitt (1998) suggests that educational systems are not ideologically neutral; every educational system incorporates biases which reflect the views and interests of those in possession of social, economic and political power. A critical adult learning perspective encourages a fundamental questioning of how 
and why our professional education and accreditation systems are constructed in the way they are, how and why uni-professional systems of education and accreditation are supported when interprofessional are not, and whose interests are served by those structures and whose interests are excluded or marginalized. If we were to examine the current health professional education system through a critical adult learning perspective we might observe that the system, including the academic accreditation system, is structured in a way that is self-serving to each profession concerned. A critical analysis of this structure would suggest that the interests and principles of collaborative, patient-centred care may not be valued in a structure which prioritizes the interests of individual professions.

Overall, the findings from this analysis of the academic accreditation systems of health professional education in Canada suggest that greater collaboration among the accrediting bodies must be fostered if we are to promote and foster IECPCP at an educational level. If we are to foster IECPCP through the educational system, then the accreditation system must encourage and promote interprofessional education through the accreditation process. The accreditation system has an important role to play in fostering educational system change and the results from this study would suggest that change at the accreditation system level needs to be encouraged and is necessary to support IECPCP at the health professional educational level.

\section{NOTES}

${ }^{1}$ Mainpro-M1 and C represent different levels of credits which can be claimed for accredited CME activities. These are accredited by the CFPC and by other organizations with which the CFPC has accreditation agreements.

\section{ACKNOWLEDGEMENTS}

This study was funded through the Health Human Resource Strategies Division, Health Canada. 


\section{REFERENCES}

Areskog, N. (1988). The need for multiprofessional health education in undergraduate studies [Editorial]. Medical Education, 22(4), 251-252.

Association of Accrediting Agencies of Canada. (2005a). Definitions. Retrieved January 11, 2005, from: http://aaac.ca/ENGLISH/HOME.HTM.

Association of Accrediting Agencies of Canada. (2005b). Bylaws. Retrieved January 11, 2005, from: http://aaac.ca/ENGLISH/BYLAW.HTM.

Association of Accrediting Agencies of Canada. (2005c). Good practice guidelines. Retrieved January 11, 2005, from: http://aaac.ca/ENGLISH/ PRACTICE.htm.

CAIPE (1997). Interprofessional education - A definition. London: Centre for the Advancement of Interprofessional Education.

Canadian Council for the Accreditation of Pharmacy Programs (2004). Accreditation standards and guidelines for pharmacy professional degree programs in Canada. Retrieved November 1, 2004, from http://www.napra.org/ docs/0/94/107/118.asp.

Canadian Nurses Association (1992). Guidelines for continuing nursing education programs. Ottawa, 0 N.

Clark, P.G. (1991). Toward a conceptual framework for developing interdisciplinary teams in gerontology: cognitive and ethical dimensions. Gerontology \& Geriatrics Education, 12(1), 79-96.

D'Amour, D., \& Oandasan, I. (2005). Interprofessionality as the field of interprofessional practice and interprofessional education: An emerging concept. Journal of Interprofessional Care, 19(Supplement 1), 8-20.

Drinka, T.J.K. (1996). Applying learning from self-directed work teams in business to curriculum development for interdisciplinary geriatric teams. Educational Gerontology, 22(5), 433-450.

Eaton, J. (2003). The value of accreditation: Four pivotal roles. Council for Higher Education Accreditation. CHEA Letter from the President. Retrieved January 6, 2005, from http://www.chea.org/pdf/pres_ltr_value_accrd_5-03.pdf.

Gelman, S. (1997). Accreditation, core curriculum and allied health education. Journal of Allied Health, 26(3), 119-125.

Gilbert, J.H.V. (2005). Interprofessional learning and higher education structural barriers. Journal of Interprofessional Care, 19(Supplement 1), 87106.

Hall, P. (2005). Interprofessional teamwork: Professional cultures as barriers. Journal of Interprofessional Care, 19(Supplement 1), 188-196. 
Hamilton, J. (1995). Establishing standards and measurement methods for medical education. Academic Medicine, 70(7), S51-S56.

Health Council of Canada (2005). Health care renewal in Canada: Accelerating change. Available from: http://hcc-ccs.com/index.aspx

Kassebaum, D. (1992). Origin of the LCME, the AAMC-AMA partnership for accreditation. Academic Medicine, 67(2), 85-87.

Kassebaum, D., \& Cohen, J. (2000). Nonaccredited medical education in the United States. The New England Journal of Medicine, 342(21), 1602-1605.

Kassebaum, D., Cutler, E., \& Eaglen, R. (1997). The influence of accreditation on educational change in U.S. medical schools. Academic Medicine, 72(12), 1128-1133.

Kirby, M.J.L. (2002). The health of Canadians - The federal role: Final report on state of the health care system in Canada. The Standing Senate Committee on Social Affairs, Science and Technology. Available from: http://www.parl.gc.ca/37/2/parlbus/commbus/senate/com-e/soci-e/rep-e/ repoct02vol6highlights-e.htm

Lahey, W., \& Currie, R. (2005). Regulatory and medico-legal barriers to interprofessional practice. Journal of Interprofessional Care, 19(Supplement 1), 197-223.

Leist, J., Gilman, S., Cullen, R. \& Sklar, J. (2004). Using Baldridge criteria to meet or exceed Accreditation Council for Continuing Medical Education standards. The Journal of Continuing Education in the Health Professions, 24(1), 57-63.

Merriam, S.B., \& Caffarella, R.S. (1999). Learning in adulthood: A comprehensive guide. $2^{\text {nd }}$ Edition. San Francisco: Jossey-Bass.

Nesbitt (1998). The social reform perspective: Seeking a better society. In D.D. Pratt (ed.), Five perspectives on teaching in adult and higher education. Malabar, FL: Krieger Publishing.

Oandasan, I., \& Reeves, S. (2005a). Key elements for interprofessional education. Part 1: The learner, the educator and the learning context. Journal of Interprofessional Care, 19(Supplement 1), 21-38.

Oandasan, I., \& Reeves, S. (2005b). Key elements for interprofessional education. Part 2: Factors, processes and outcomes. Journal of Interprofessional Care, 19(Supplement 1), 39-48.

Parsell, G., Spalding, R., \& Bligh, J. (1998). Shared goals, shared learning: evaluation of a multiprofessional course for undergraduate students. Medical Education, 32(3), 304-311.

Parsell, G. \& Bligh J. (1999). Interprofessional learning. Medical Education, 33(9), 632-3. 
Reeves, S., \& Freeth, D. (2002). The London training ward: an innovative interprofessional learning initiative. Journal of Interprofessional Care, 16(1), 45-52.

Romanow, R. (2002). Building on values: The future of health care in Canada. The Romanow Report. Saskatoon, SK: Commission on the Future of Health Care in Canada. Retrieved October 10, 2005, from http://www.hc-sc.gc. ca/english/care/romanow/index 1.html.

Schwarz, M. R. (1992). Liaison Committee on Medical Education: Past successes, future challenges. Journal of the American Medical Association, 268 (9), 1091-1092.

Sullivan, M. (1994). Accreditation of postsecondary education and the role of allied health in specialized accreditation. AARC Times, 18(1), 38-43.

Thomas, B. \& Arsenault, A. (1993). Accreditation of university schools of nursing: The Canadian experience. International Nursing Review, 40(3), 81-94.

Thomas, B., Arsenault, A., Bouchard, J, Coté, E., \& Stanton, S. (1992). Accreditation of university nursing programmes in Canada. Canadian Journal of Nursing Research, 24(2), 33-48.

Welton, M.R. (1993). The contribution of critical theory to our understanding of adult learning. In S.B. Merriam (ed.), An update on adult learning theory. New Directions for Adult and Continuing Education, no.57. San Francisco: Jossey-Bass.

World Health Organization. (1988). Learning together to work together for health. Technical Report Series 769. Geneva, WHO.

\section{CONTACT INFORMATION}

Vernon Curran, PhD Associate Professor Faculty of Medicine Memorial University of Newfoundland St. John's, NL

A1B 3V6

Phone: 709-777-7542

Fax: 709-777-6576

Email:vcurran@mun.ca 
Appendix A

Accrediting Bodies and Accreditation Standard Categories for Canadian Health Professional Education Programs

\begin{tabular}{|c|c|c|}
\hline $\begin{array}{l}\text { Accrediting Body } \\
\text { and Accreditation } \\
\text { Documents Reviewed }\end{array}$ & Accreditation Elements & $\begin{array}{c}\text { Accreditation } \\
\text { Standard Categories }\end{array}$ \\
\hline \multicolumn{3}{|l|}{ Medicine (undergraduate) } \\
\hline $\begin{array}{l}\text { * Committee on Accreditation } \\
\text { of Canadian Medical Schools } \\
\text { (CACMS)/Liaison Committee } \\
\text { for Medical Education (LCME) } \\
\text { * Liaison Committee on } \\
\text { Medical Education. (2004). } \\
\text { Functions and structure of } \\
\text { a medical school: Standards } \\
\text { for accreditation of medical } \\
\text { education programs leading } \\
\text { to the M.D. degree. Retrieved } \\
\text { October 6, 2004, from } \\
\text { http://www.lcme.org/pubs. } \\
\text { htm\#fands. }\end{array}$ & $\begin{array}{l}\text { * } 8 \text { year accreditation cycle } \\
\text { * Self-study process and } \\
\text { development of an } \\
\text { institutional database and } \\
\text { self-study report } \\
\text { * 4-day site visit }\end{array}$ & $\begin{array}{l}\text { * Institutional Setting } \\
\text { - governance and } \\
\text { administration, academic } \\
\text { environment; } \\
\text { * Educational Program for the } \\
\text { M.D. Degree - educational } \\
\text { objectives, structure, teaching } \\
\text { and evaluation, curriculum } \\
\text { management, evaluation of } \\
\text { program effectiveness; } \\
\text { * Medical Students - } \\
\text { admissions, student services, } \\
\text { the learning environment; } \\
\text { * Faculty - numbers, } \\
\text { qualifications, functions, } \\
\text { personnel policies, } \\
\text { governance; } \\
\text { * Educational Resources - } \\
\text { finances, general facilities, } \\
\text { clinical teaching facilities, } \\
\text { information resources and } \\
\text { library services. }\end{array}$ \\
\hline
\end{tabular}

Medicine (postgraduate - Family Medicine)

* College of Family Physicians of Canada (CFPC)

* College of Family Physicians of Canada. (2004). Standards

for accreditation of residency training programs: Family medicine; Emergency medicine; enhanced skills; Palliative medicine. (The Red Book). Retrieved October 6, 2004, from http://www.cfpc. ca/English/cfpc/education/ acceditation/default.asp?s=1
* 6 year accreditation cycle

* Pre-survey documentation and site visit
Standards for accreditation are based on the following four principles of family medicine:

* The family physician is a skilled clinician.

* Family medicine is community-based.

* The family physician is a resource to a defined practice population.

* The doctor-patient relationship is central to the role of the family physician. 


\begin{tabular}{|c|c|c|}
\hline $\begin{array}{c}\text { Accrediting Body } \\
\text { and Accreditation } \\
\text { Documents Reviewed }\end{array}$ & Accreditation Elements & $\begin{array}{c}\text { Accreditation } \\
\text { Standard Categories }\end{array}$ \\
\hline \multicolumn{3}{|c|}{ Medicine (postgraduate - Specialty training) } \\
\hline $\begin{array}{l}\text { * Royal College of Physicians } \\
\text { and Surgeons of Canada } \\
\text { (RCPSC) } \\
\text { * Royal College of Physicians } \\
\text { and Surgeons of Canada. } \\
\text { (2004c). Guide for the } \\
\text { accreditation of national } \\
\text { specialty societies. Ottawa, } \\
\text { ON: RCPSC. }\end{array}$ & $\begin{array}{l}\text { *3 categories of approval: } \\
\text { approval (6 years); } \\
\text { provisional approval } \\
\text { (requires a progress report } \\
\text { or another site review } \\
\text { within } 2 \text { years); notice } \\
\text { of intent to withdraw } \\
\text { accreditation } \\
\text { * Pre-survey documentation } \\
\text { and site survey in } \\
\text { cooperation with the CFPC }\end{array}$ & $\begin{array}{l}\text { Standards of RCPSC } \\
\text { accreditation are organized } \\
\text { around the following } \\
\text { groupings: } \\
\text { * Administration } \\
\text { * Goals and objectives } \\
\text { * Organization of program } \\
\text { * Resources } \\
\text { * Academic/scholarly } \\
\text { components } \\
\text { * Evaluation } \\
\text { The Canadian Medical } \\
\text { Education Directions } \\
\text { for Specialists 2000 } \\
\text { Project (CanMEDS) } \\
\text { framework and roles } \\
\text { are a central element } \\
\text { for standards of } \\
\text { postgraduate medical } \\
\text { education. Detailed } \\
\text { guidelines within } \\
\text { the above groups of } \\
\text { standards refer to } \\
\text { the CanMEDS roles } \\
\text { of medical expert, } \\
\text { communicator, } \\
\text { collaborator, } \\
\text { manager, health } \\
\text { advocate, scholar, and } \\
\text { professional. }\end{array}$ \\
\hline
\end{tabular}




\begin{tabular}{|c|c|c|}
\hline $\begin{array}{l}\text { Accrediting Body } \\
\text { and Accreditation } \\
\text { Documents Reviewed }\end{array}$ & Accreditation Elements & $\begin{array}{c}\text { Accreditation } \\
\text { Standard Categories }\end{array}$ \\
\hline \multicolumn{3}{|c|}{ Medicine (CME - Family Physicians) } \\
\hline $\begin{array}{l}\text { * Committee on Accreditation } \\
\text { of Continuing Medical } \\
\text { Education (CACME) } \\
\text { * Collège des Médecins du } \\
\text { Québec (CMQ) } \\
\text { * Fédération des médecins } \\
\text { omnipracticiens du Québec } \\
\text { (FM0Q) } \\
\text { * Association des medecins de } \\
\text { langue francaise du Canada } \\
\text { (AMLFC) } \\
\text { * College of Family Physicians } \\
\text { of Canada (CFPC) } \\
\text { * Committee on the } \\
\text { Accreditation of Continuing } \\
\text { Medical Education (2004). } \\
\text { The accreditation of Canadian } \\
\text { university CME offices. } \\
\text { * College of Family Physicians } \\
\text { of Canada. (2004). Mainpro } \\
\text { - Background information. } \\
\text { Retrieved October 6, 2004, } \\
\text { from http://www.cfpc.ca/ } \\
\text { English/cfpc/cme/mainpro/ } \\
\text { maintenance\%20of\%20profi } \\
\text { ciency/ background\%20info/ } \\
\text { default.asp?s=1 } \\
\text { * College of Family Physicians } \\
\text { of Canada. (2005). Mainpro } \\
\text { - Mainpro-M1 and Mainpro- } \\
\text { C accreditation criteria for } \\
\text { courses. Retrieved January } \\
\text { 12, 2005, from http://www. } \\
\text { cfpc.ca/English/cfpc/ } \\
\text { cme/mainpro/maintenan } \\
\text { ce\%20of\%20proficiency/ } \\
\text { m1\%20and\%20c\%20criteria/ } \\
\text { default.asp?s=1. } \\
\text { * College of Family Physicians } \\
\text { of Canada. (2005). } \\
\text { Mainpro-M1 accreditation } \\
\text { of conferences, courses } \\
\text { and workshops. Retrieved } \\
\text { January 12, 2005, from } \\
\text { http://www.cfpc.ca/English/ } \\
\text { cfpc/cme/mainpro/mainte } \\
\text { nance\%20of\%20proficienc } \\
\text { y/m1\%20app\%20process/ } \\
\text { default.asp?s=1. }\end{array}$ & $\begin{array}{l}{ }^{*} \text { Pre-survey report and a } \\
\text { site visit } \\
{ }^{*} \text { Accreditation is granted } \\
\text { for a maximum of } 5 \text { years }\end{array}$ & $\begin{array}{l}\text { * The following criteria are } \\
\text { required for both Mainpro-M1 } \\
\text { and Mainpro-C accreditation: } \\
\text { * At least one member of the } \\
\text { CFPC has had substantial } \\
\text { input into the program. } \\
\text { * The educational content is } \\
\text { relevant to family medicine. } \\
\text { * Learning objectives have } \\
\text { been defined according to the } \\
\text { learning needs of participants } \\
\text { and will have been provided } \\
\text { to them prior to the program. } \\
\text { * Organizers will have provided } \\
\text { specific instructions to } \\
\text { speakers regarding their } \\
\text { involvement. The format } \\
\text { and environment will be } \\
\text { appropriate for learning. } \\
\text { * Participants will have an } \\
\text { opportunity to evaluate the } \\
\text { program. } \\
\text { * The planning, content, and } \\
\text { conduct of the program } \\
\text { follow acceptable ethical } \\
\text { standards. } \\
\text { * For Mainpro-C accreditation, } \\
\text { there is an activity after the } \\
\text { program that encourages } \\
\text { participants to reflect on what } \\
\text { they have learned. }\end{array}$ \\
\hline
\end{tabular}




\begin{tabular}{|c|c|c|}
\hline $\begin{array}{l}\text { Accrediting Body } \\
\text { and Accreditation } \\
\text { Documents Reviewed }\end{array}$ & Accreditation Elements & $\begin{array}{c}\text { Accreditation } \\
\text { Standard Categories }\end{array}$ \\
\hline Medicine (CME - Specialists) & & \\
\hline $\begin{array}{l}\text { * Committee on Accreditation } \\
\text { of Continuing Medical } \\
\text { Education (CACME) } \\
\text { * Royal College of Physicians } \\
\text { and Surgeons of Canada } \\
\text { (RCPSC) } \\
\text { * Committee on the } \\
\text { Accreditation of Continuing } \\
\text { Medical Education (2004). } \\
\text { The accreditation of Canadian } \\
\text { university CME offices. } \\
\text { * Royal College of Physicians } \\
\text { and Surgeons of Canada. } \\
\text { (2004). Maintenance of } \\
\text { Certification - General } \\
\text { information. Retrieved October } \\
\text { 6, 2004, from http://rcpsc. } \\
\text { medical.org/maintenance/. } \\
\text { * Royal College of Physicians } \\
\text { and Surgeons of Canada. } \\
\text { (2004). Application form: } \\
\text { Approval of accredited group } \\
\text { learning activities. Retrieved } \\
\text { January 12, 2005, from http:// } \\
\text { rcpsc.medical.org/opd/forms/ } \\
\text { approvalform_e.pdf. }\end{array}$ & $\begin{array}{l}\text { * RCPSC accepts CACME } \\
\text { accreditation for } \\
\text { universities } \\
\text { * National specialty } \\
\text { societies have to apply to } \\
\text { the RCPSC }\end{array}$ & $\begin{array}{l}\text { General criteria for the } \\
\text { accreditation of programs } \\
\text { under Section } 1 \text { of Maincert: } \\
\text { * The activity must be planned } \\
\text { to address the identified needs } \\
\text { of the target audience. } \\
\text { * The activity must create } \\
\text { learning objectives to address } \\
\text { identified needs. } \\
\text { * At least } 25 \% \text { of the total } \\
\text { education time must be } \\
\text { devoted to interactive } \\
\text { learning strategies. } \\
\text { * The activity includes an } \\
\text { evaluation of learning for } \\
\text { practice. } \\
\text { * The activity approved must } \\
\text { meet the CMA Guidelines } \\
\text { governing the relationship } \\
\text { between physicians and the } \\
\text { pharmaceutical industry. }\end{array}$ \\
\hline
\end{tabular}




\begin{tabular}{|c|c|c|}
\hline $\begin{array}{c}\text { Accrediting Body } \\
\text { and Accreditation } \\
\text { Documents Reviewed }\end{array}$ & Accreditation Elements & $\begin{array}{c}\text { Accreditation } \\
\text { Standard Categories }\end{array}$ \\
\hline Nursing (pre-licensure) & & \\
\hline $\begin{array}{l}\text { * Canadian Association of } \\
\text { Schools of Nursing (CASN) } \\
{ }^{*} \text { Canadian Association of } \\
\text { Schools of Nursing. (1995). } \\
\text { CASN Accreditation Program. } \\
\text { Ottawa, ON: Canadian } \\
\text { Association of Schools of } \\
\text { Nursing. } \\
\text { * Canadian Association of } \\
\text { Schools of Nursing. (2004). } \\
\text { Accreditation Process. } \\
\text { Retrieved October 29, 2004, } \\
\text { from http://www.causn.org/ } \\
\text { Accreditation/accrediation_- } \\
\text { process.htm. } \\
\text { Canadian Nurses Association } \\
\text { (1992). Guidelines for } \\
\text { continuing nursing education } \\
\text { programs. Ottawa, ON: } \\
\text { Canadian Nurses Association. }\end{array}$ & $\begin{array}{l}\text { * Self-study and on-site } \\
\text { review } \\
\text { * Accreditation can be } \\
\text { granted for the maximum } \\
\text { term of } 7 \text { years, for } 5 \\
\text { years or denied }\end{array}$ & $\begin{array}{l}\text { * Relevance: The extent to } \\
\text { which the mission and } \\
\text { goals of a program reflect a } \\
\text { response to the major trends } \\
\text { in society that impact on } \\
\text { the health needs, present } \\
\text { and future, of the larger } \\
\text { community. } \\
\text { * Accountability: The extent to } \\
\text { which the program teaches } \\
\text { the student that the primary } \\
\text { responsibility in nursing } \\
\text { is to the client, that is, the } \\
\text { community, group, family } \\
\text { and/or person. } \\
\text { * Relatedness: The extent to } \\
\text { which the components of a } \\
\text { program support and build on } \\
\text { other parts, thereby promoting } \\
\text { or negating the achievements } \\
\text { of goals. The components } \\
\text { are: } 1 \text { ) curriculum, 2) the } \\
\text { teaching of nursing, 3) } \\
\text { research, clinical practice, and } \\
\text { professional activities, and 4) } \\
\text { administration. } \\
\text { * Uniqueness: The extent to } \\
\text { which a program capitalizes } \\
\text { on unique characteristics } \\
\text { of its resources (faculty, } \\
\text { community values, financial } \\
\text { support) within its particular } \\
\text { setting. }\end{array}$ \\
\hline
\end{tabular}




\begin{tabular}{|c|c|c|}
\hline $\begin{array}{c}\text { Accrediting Body } \\
\text { and Accreditation } \\
\text { Documents Reviewed }\end{array}$ & Accreditation Elements & $\begin{array}{c}\text { Accreditation } \\
\text { Standard Categories }\end{array}$ \\
\hline \multicolumn{3}{|l|}{ Pharmacy (pre-licensure) } \\
\hline $\begin{array}{l}\text { * Canadian Council for the } \\
\text { Accreditation of Pharmacy } \\
\text { Programs (CCAPP) } \\
\text { * Canadian Council for the } \\
\text { Accreditation of Pharmacy } \\
\text { Programs (2004). Accreditation } \\
\text { Standards and Guidelines } \\
\text { for Pharmacy Professional } \\
\text { Degree Programs in Canada. } \\
\text { Retrieved November 1, 2004, } \\
\text { from http://www.napra.org/ } \\
\text { docs/0/94/107/118.asp. }\end{array}$ & $\begin{array}{l}\text { * Self-examination and } \\
\text { site visit } \\
\text { * Accreditation can be } \\
\text { granted for up to } 6 \text { years } \\
\text { (full accreditation); } 3 \text { year } \\
\text { conditional accreditation; } \\
\text { or a } 1 \text { year probationary } \\
\text { accreditation }\end{array}$ & $\begin{array}{l}\text { * Mission, planning, and } \\
\text { assessment - faculty mission } \\
\text { and goals, systematic } \\
\text { planning, systematic } \\
\text { assessment of achievement; } \\
\text { * Organization and } \\
\text { administration - faculty- } \\
\text { university relationships, } \\
\text { organizational and } \\
\text { administrative relationships } \\
\text { in university and affiliated } \\
\text { health care facilities; } \\
\text { * The academic program } \\
\text { - educational outcomes, } \\
\text { program organization and } \\
\text { length, curriculum content, } \\
\text { teaching and learning } \\
\text { processes, student assessment, } \\
\text { curriculum evaluation; } \\
\text { * Students - admission criteria, } \\
\text { policies, and procedures, } \\
\text { student services, student } \\
\text { representation, student/faculty } \\
\text { relationships; } \\
\text { * Faculty and staff; } \\
\text { * Library and learning } \\
\text { resources; } \\
\text { * Physical and practice } \\
\text { facilities; and } \\
\text { * Financial resources. }\end{array}$ \\
\hline
\end{tabular}




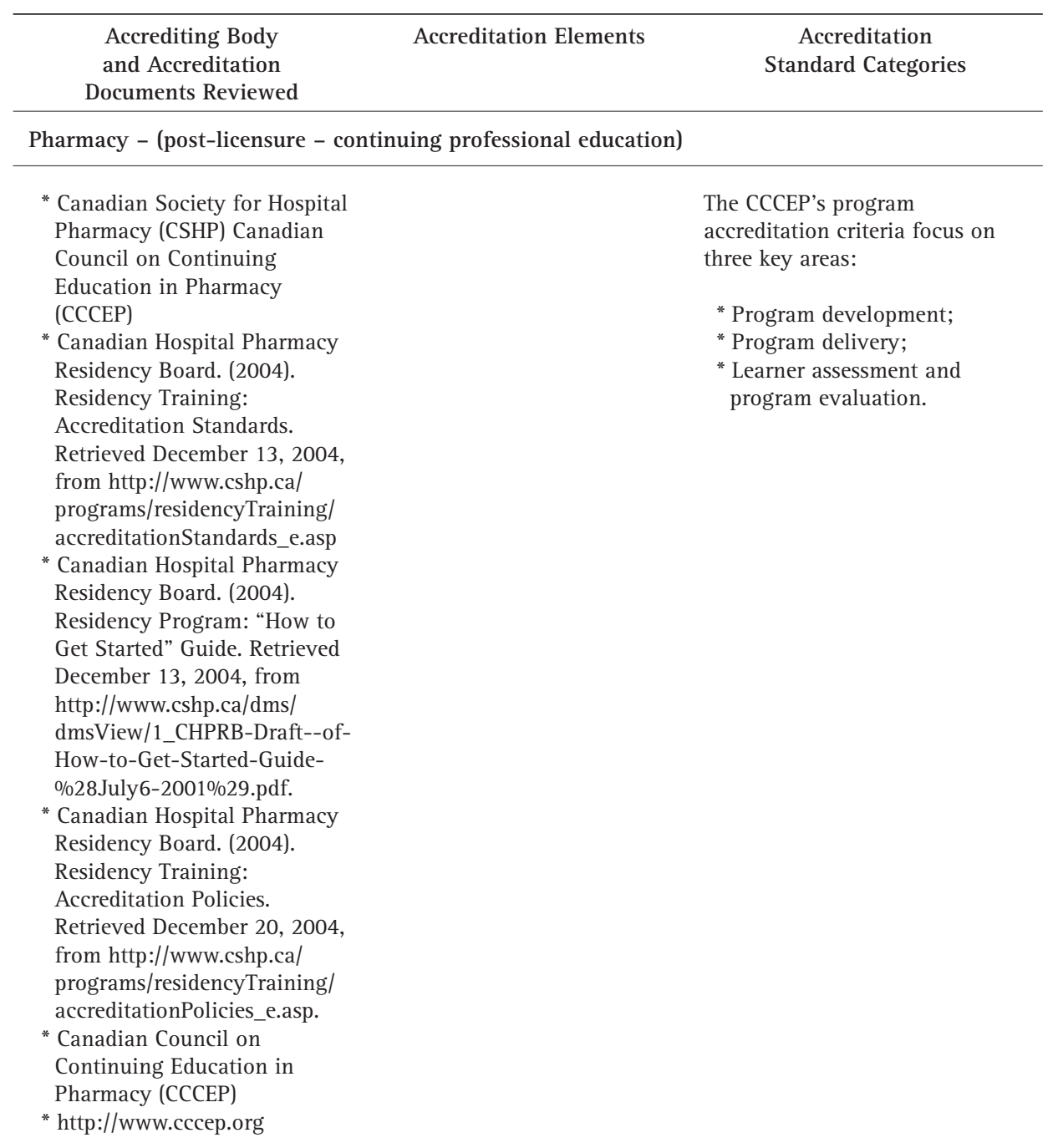




\begin{tabular}{|c|c|c|}
\hline $\begin{array}{c}\text { Accrediting Body } \\
\text { and Accreditation } \\
\text { Documents Reviewed }\end{array}$ & Accreditation Elements & $\begin{array}{c}\text { Accreditation } \\
\text { Standard Categories }\end{array}$ \\
\hline \multicolumn{3}{|c|}{ Social Work (pre- and post-licensure) } \\
\hline $\begin{array}{l}\text { * Canadian Association } \\
\text { of Schools of Social } \\
\text { Work (CASSW) Board of } \\
\text { Accreditation } \\
\text { * Canadian Association of } \\
\text { Schools of Social Work. } \\
\text { (2004). CASSW Procedures } \\
\text { of Accreditation. Retrieved } \\
\text { November 1, 2004, from } \\
\text { http://www.cassw-acess.ca/ } \\
\text { xACCR/ac1x2.htm. } \\
\text { * Canadian Association of } \\
\text { Schools of Social Work. } \\
\text { (2004). CASSW Standards for } \\
\text { Accreditation (May 4, 2004). } \\
\text { Retrieved November 1, 2004, } \\
\text { from http://www.cassw-acess. } \\
\text { ca/xACCR/ac1x2.htm. } \\
\text { * Canadian Association of } \\
\text { Schools of Social Work. } \\
\text { (2004). Educational Policy } \\
\text { Statements. Retrieved } \\
\text { November 1, 2004, from } \\
\text { http://www.cassw-acess.ca/ } \\
\text { xACCR/ac1x2.htm. }\end{array}$ & $\begin{array}{l}\text { * Self-study and site visit } \\
\text { * Board of Accreditation } \\
\text { can accredit programs } \\
\text { for } 4,2 \text {, or no years if } \\
\text { deficiencies are identified }\end{array}$ & $\begin{array}{l}\text { * Mission statements; } \\
\text { * Structure, administration, } \\
\text { governance, and resources; } \\
\text { * Faculty and professional } \\
\text { staff; } \\
\text { * Students; } \\
\text { * Standards for accreditation } \\
\text { applicable to programs at } \\
\text { the first university level } \\
\text { (undergraduate social work } \\
\text { degrees) and the second } \\
\text { university level (programs } \\
\text { requiring a previous social } \\
\text { work or other undergraduate } \\
\text { degree); and } \\
\text { * Field education standards for } \\
\text { each of the above levels. }\end{array}$ \\
\hline
\end{tabular}




\begin{tabular}{|c|c|c|}
\hline $\begin{array}{l}\text { Accrediting Body } \\
\text { and Accreditation } \\
\text { Documents Reviewed }\end{array}$ & Accreditation Elements & $\begin{array}{c}\text { Accreditation } \\
\text { Standard Categories }\end{array}$ \\
\hline \multicolumn{3}{|l|}{ Physiotherapy (pre-licensure) } \\
\hline $\begin{array}{l}\text { * Accreditation Council for } \\
\text { Canadian Physiotherapy } \\
\text { Academic Programs (ACCAP) } \\
\text { * Accreditation Council for } \\
\text { Canadian Physiotherapy } \\
\text { Programs. (2004). } \\
\text { Accreditation Standards. } \\
\text { Retrieved November 1, 2004, } \\
\text { from http://www.accpap.ca/ } \\
\text { accreditationstandards.html. } \\
\text { * Canadian Physiotherapy } \\
\text { Association (2004). } \\
\text { Accreditation: Philosophy, } \\
\text { purpose, vision and } \\
\text { beliefs. Retrieved January } \\
\text { 13, 2005, from http:// } \\
\text { www.physiotherapy.ca/ } \\
\text { accreditation.htm. }\end{array}$ & $\begin{array}{l}\text { * Cycle of accreditation is } \\
6 \text { years } \\
\text { * Self-study report and on- } \\
\text { site review }\end{array}$ & $\begin{array}{l}\text { * The Program \& Its } \\
\text { Environment: The program } \\
\text { has adequate resources } \\
\text { and works closely with } \\
\text { the university, practice } \\
\text { community and the public } \\
\text { to identify changing } \\
\text { health needs and prepare a } \\
\text { workforce that can respond to } \\
\text { and meet community assets } \\
\text { and needs. } \\
\text { * Faculty: The program has } \\
\text { sufficient qualified faculty } \\
\text { for effective program design } \\
\text { and instruction, and provides } \\
\text { appropriate, periodic and } \\
\text { ongoing faculty development } \\
\text { and evaluation. } \\
\text { * Students: The program } \\
\text { prepares students with the } \\
\text { skills, knowledge, and abilities } \\
\text { relevant to physiotherapy } \\
\text { practice and regularly assesses } \\
\text { their competencies and } \\
\text { achievements. } \\
\text { * Program Evaluation: The } \\
\text { program has in place } \\
\text { an effective process of } \\
\text { continuous self-assessment, } \\
\text { planning and improvement. } \\
\text { * Accountability: The program } \\
\text { accurately represents itself } \\
\text { publicly and provides } \\
\text { sufficient information to } \\
\text { ensure accountability and } \\
\text { consumer choice. } \\
\text { * Physiotherapy Competencies: } \\
\text { The education program } \\
\text { facilitates the achievement } \\
\text { of student learning outcomes } \\
\text { related to entry-level } \\
\text { physiotherapy practice that } \\
\text { reflect current physical } \\
\text { therapy practice, emerging } \\
\text { trends in the health system } \\
\text { and advances in physical } \\
\text { therapy theory and } \\
\text { technology. }\end{array}$ \\
\hline
\end{tabular}




\begin{tabular}{|c|c|c|}
\hline $\begin{array}{c}\text { Accrediting Body } \\
\text { and Accreditation } \\
\text { Documents Reviewed }\end{array}$ & Accreditation Elements & $\begin{array}{c}\text { Accreditation } \\
\text { Standard Categories }\end{array}$ \\
\hline \multicolumn{3}{|l|}{ Occupational Therapy } \\
\hline $\begin{array}{l}\text { * Canadian Association of } \\
\text { Occupational Therapists } \\
\text { (CAOT) } \\
\text { * Canadian Association of } \\
\text { Occupational Therapists. } \\
\text { (2004). Canadian Guidelines } \\
\text { for Fieldwork Education } \\
\text { in Occupational Therapy } \\
\text { (CGFEOT). Retrieved October } \\
\text { 29, 2004, from http://www. } \\
\text { caot.ca/default.asp?pageid=42. } \\
\text { * Canadian Association of } \\
\text { Occupational Therapists. } \\
\text { (2004). Academic } \\
\text { Credentialing Council: Terms } \\
\text { of Reference. Electronic copy } \\
\text { by email from D. Klaiman, } \\
\text { December 8, 2004. }\end{array}$ & $\begin{array}{l}\text { * Self-study and site visit } \\
{ }^{*} \text { Accreditation can be } \\
\text { awarded for a maximum } \\
\text { of } 7 \text { years, } 5 \text { or } 0 \text { years } \\
\text { if considerable non- } \\
\text { compliance is present }\end{array}$ & $\begin{array}{l}\text { Standards address: } \\
\text { * the nature of the educational } \\
\text { experience; } \\
\text { * expectations for students; } \\
\text { * expectations for educators; } \\
\text { * expectations for coordinators } \\
\text { * information on OT } \\
\text { services provided, learning } \\
\text { opportunities and resources, } \\
\text { administrative resources, } \\
\text { amenities, site requirements } \\
\text { for students. }\end{array}$ \\
\hline
\end{tabular}

